\title{
A Tribute to Charlie Bayliff
}

$\mathrm{T}$

The hospital pharmacy community was shocked and January 24, 2010.

I was privileged to work with Charlie in a variety of ways over the years. I first met Charlie in the early ' 80 s when he joined Sunnybrook Medical Centre as a clinical coordinator before moving on to what is now called the London Health Sciences Centre. We worked together again when Charlie was an Associate Editor for the CJHP, from October 1992 to May 1998.

Charlie was an easy-going, personable individual, always ready with a joke or humorous anecdote. His enthusiasm, wide-eyed grin, and infectious smile made him someone you wanted to spend time with. However, it was his dedication and commitment to pharmacy that set him apart and made him an important influence on the profession in Canada. He was a member of the CSHP for more than 25 years, was awarded a CSHP Fellowship in 1996, and was winner of the Society's Distinguished Service Award in 2001.

Charlie once told me he was an "ideas man". Combined with his enthusiasm and sound logic, his ideas were infectious. Beyond patient care, his passion focused on teaching and training. In this, he served as a role model for us all. In London, Charlie was heavily involved in the hospital pharmacy residency program, and he served as a preceptor for PharmD rotations for students from the University of Toronto. Charlie encouraged his residents and PharmD students to publish case reports as a way of meshing clinical training and research. ${ }^{1}$ His encouragement in this area inadvertently led to Charlie likely coauthoring more case reports published in the CJHP than anyone else in Canada. This also placed him at the centre of a discussion about one of the CJHP's editorial policies: Charlie was troubled that issues related to patient confidentiality and informed consent might constrain the dissemination of information, which could ultimately affect patient care. Our discussion of this matter developed into one of the early Point Counterpoint debates published in the CJHP. ${ }^{2}$

His immersion in and dedication to the profession of pharmacy put him in touch with many "hot button" issues, ${ }^{3}$ and Charlie frequently wrote letters to the editor in response to CJHP publications. His view was always close to the pulse of the profession, often worthy of a sober second thought and frequently focusing on patient safety. ${ }^{4}$

Our profession has lost a visionary and a role model. Charlie will be missed and remembered by his family, friends, colleagues, past students, and the many patients whose care he improved. Good-bye, old friend. We are all better for having known you. Godspeed, dear Charlie.

- Scott Walker, with assistance from Bill Bartle, Jim Mann, and Sandra Walker

\section{References}

1 Lindblad AJ, Bayliff CD, Hergott CA. Anagrelide-induced pneumonitis: case report and review of the literature. Can J Hosp Pharm 2008:61(3); 210-212.

2. Bayliff CD. Should informed consent be required to publish a case report? The "con" side. Can J Hosp Pharm 2007;60(5):336-337.

3. Mills A, Bayliff CD. Is the prioritization of medication reconciliation as a critical activity the best use of pharmacists' time? The "con" side. Can J Hosp Pharm 2008;61(2):150-151.

4. Bayliff CD. The formulary system reconsidered [letter]. Can J Hosp Pharm 2007;60(5):339. 